\title{
Some functional characteristics of extruded blends of fiber from sugarcane bagasse, whey protein concentrate, and corn starch
}

\author{
Características funcionais de misturas extrusadas de fibra de bagaço de cana de açúcar,
} concentrado protéico de soro de leite e amido de milho

\author{
Fernando MARTÍNEZ-BUSTOS ${ }^{1 *}$, Rubí VIVEROS-CONTRERAS ${ }^{2}$, Tomás GALICIA-GARCÍA ${ }^{1}$, \\ Elizabeth Harumi NABESHIMA³ ${ }^{3}$ Iñigo VERDALET-GUZMÁN ${ }^{2}$
}

\begin{abstract}
Blends of fiber from sugar cane bagasse, corn starch, and whey protein concentrate were extruded. A single screw extruder, equipped with a screw at a constant compression ratio of 1:1 and a die diameter of $3 \mathrm{~mm}$, was used. The best processing conditions were determined according to a central composite rotatable design $(\alpha=1.41)$ with 5 central points, which gives a total of 13 tests. During the extrusion process the content of insoluble fiber decreased and that of soluble fiber increased. An increase in the contents of fiber and in the barrel temperature resulted in a decrease in the expansion index values and an increase in the water absorption index values; whereas in blends with intermediate fiber contents the effects in these parameters were found to be the opposite. High fiber contents increased penetration force but decreased luminosity, water solubility index values and the adhesive force in gels. The extrusion process improved the functional properties of sugarcane fiber bagasse enabling its addition to diverse alimentary systems.

Keywords: extrusion; sugarcane bagasse fiber; dietary fiber; whey protein concentrate; corn starch.
\end{abstract}

\section{Resumo}

Misturas de fibra do bagaço da cana-de-açúcar, amido de milho e concentrado proteico de soro de leite foram extrusadas. Neste estudo, foi utilizado extrusor monorrosca, utilizando parafuso com taxa de compressão de 1:1 e matriz de 3 mm de diâmetro. As melhores condições de processamento foram determinadas de acordo com um delineamento central composto rotacional $(\alpha=1,41)$ com 5 pontos centrais, totalizando 13 tratamentos. Durante o processo de extrusão, o teor de fibra insolúvel foi diminuído e o teor de fibra solúvel aumentado. Com o aumento dos teores de fibra das misturas e da temperatura de extrusão, ocorreu a diminuição do índice de expansão e o aumento do índice de absorção de água; entretanto, para as misturas com teores intermediários de fibra, os efeitos nestes parâmetros foram contrários. Teores elevados de fibra das misturas aumentaram a força de penetração e diminuíramo índice de luminosidade, a solubilidade em água e a força de adesividade dos géis. O processo de extrusão melhorou as propriedades funcionais da fibra do bagaço de cana de açúcar, possibilitando sua adição em sistemas alimentares diversos.

Palavras-chave: extrusão; fibra de bagaço de cana; fibra alimentar; concentrado protéico de soro de leite; amido de milho.

\section{Introduction}

Diets with a high content of fat and calories are considered to be a major cause of coronary heart disease, obesity, and diabetes Mellitus. The consumption of fiber and some insoluble fibers from fruits, cereals, and vegetable by-products could retard the utilization and absorption of carbohydrates, diminish the glycemic response in diabetics, and control the serous glucose level (ROSAMOND, 2002). It is known that dietary fibers can be used effectively to control hyperglycemia, and it generally affected by factors such as origin, composition and methods of preparation (SCHAEFER et al., 2001). The market for dietary fiber is highly competitive, and new alimentary fibers must have the nutritional and physiological properties required to satisfy the market demands of consumers. At present, there has been a great variety of agricultural by-products from which to obtain dietary fiber (PANDEY et al., 2000; LARREA et al., 2005a; AGUILAR-PALAZUELOS et al., 2007). Starch is a natural polymer that enhances the functional characteristics of diverse alimentary formulations and has a high potential for use in the development of new products (MORARU; KOKINI, 2003) since it has a variety of applications attributable to its facility of modification. Whey proteins present a wide range of synergetic uses in foods together with other components because of their properties of solubility, viscosity, water retention, gelation, and emulsification. They are also an excellent source of amino-acids, which make them appropriate for supplementing fortified foods (HUFFMAN, 1996). A number of Latin American countries generate large volumes of sugarcane bagasse that normally are most commonly used as fuel. This

${ }^{1}$ Ciencia de Materiales, CINVESTAV Querétaro, Apdo. Postal 1-798, Querétaro, Qro., 76230, México, e-mail: fmartinez@qro.cinvestav.mx

2 Instituto de Ciencias Básicas, Col. Industrial-Animas, Xalapa, Veracruz, México

${ }^{3}$ Instituto de Tecnologia de Alimentos - ITAL, Centro de Tecnologia de Cereais e Chocolates, Cereal Chocotec, Campinas, SP, Brasil

* Corresponding author 
bagasse is composed mainly of cellulose, hemi-cellulose, and lignin (BARQUINERO, 1999). The use of by-products derived from sugarcane, principally the fiber contained in the bagasse that is generated during the extraction of the cane juice, can be modified to improve their functional properties. Using extrusion processing to modify fiber, is a promising method for enhancing the functional properties of foods (LARREA et al., 2005a; AGUILAR-PALAZUELOS et al., 2007). Many commercially available products are made from bagasse such as $\alpha$-cellulose and purified hemicellulose (KURAKAKE et al., 1991), but processing is expensive and requires sophisticated technology. Bagasse is also used in healthy foods formulated with dietary fiber (FERNANDEZ et al., 1996; ARRIGONI et al., 1986; GOURGUE et al., 1994; GAJULA et al., 2008). Several researchers have shown the potential use of fibers by using extrusion and other thermo-mechanical processes in order to improve the fibers' functional properties and to increase their incorporation into breadmaking products (FERNANDEZ et al., 1996; GAJULA et al., 2008; SANGNARK; NOOMHORM, 2004), meat products, dehydrated gravies, puddings, feed and extruded snacks (CAMIRE; KING, 1991; KESTERSON; BRADDOCK, 1973), enriched extruded wheat flour, cookies, and tortillas (GOULD et al., 1989; RANHOTRA et al., 1991; LARREA et al., 2005b; BERGLUND et al., 1994; SODINI et al., 2005; GIUNTINI et al., 2003). However, attempts to incorporate high levels of fiber into extruded products often give them a compact and resistant texture, neither crunchy nor desirable, as a result of reduced expansion (LARREA et al., 2005a; AGUILAR-PALAZUELOS et al., 2007; GOURGUE et al., 1994; GAJULA et al., 2008); although expanded extruded products can be milled and the resulting precooked flours can increase their incorporation into foods. The purpose of the present study was to analyze some physicochemical characteristics of extruded flour blends of sugarcane fiber, whey protein, and corn starch to determine whether they can be formulated in food systems.

\section{Material and methods}

\subsection{Raw materials}

The sugarcane bagasse was obtained from El Modelo sugar mill (Veracruz, Mexico). The whey protein concentrate (WPC 35) was acquired from America Foods (Mexico City, D.F.), and the corn starch from Corn Products Ingredients (Querétaro, Mexico).

\subsection{Separation and cleaning of fibers}

The bagasse fibers separated from the parenchyma were washed and milled until a particle size smaller than $300 \mu$ was obtained. Next, they were blended with whey protein concentrate and corn starch.

\subsection{Preparation of raw material}

The moisture content and the proportions of the components were conditioned according to the experimental design shown in Table 1. The concentration of the other ingredients (CS: Corn starch and WPC: Whey protein concentrate) was established in experimental previous studies (VERDALET-GUZMÁN et al., 2007). Distilled water was used and each blend was sifted to ensure homogeneity. The final moisture content $( \pm 0.2 \%)$ was measured using a thermobalance (OHAUS MB200, Florham $\mathrm{PK}, \mathrm{NJ}),\left(160^{\circ} \mathrm{C} / 0.01 \mathrm{~g} / 20 \mathrm{~s}\right)$. The samples were placed in plastic bags and stored in refrigeration at $4^{\circ} \mathrm{C}$ for 8 hours to ensure a homogeneous distribution of the water.

\subsection{Extrusion process}

The raw blends were processed in a laboratory single screw extruder (CINVESTAV, Queretaro, Mexico) at a compression ratio of $1: 1$ and a circular die with an exit opening of $3 \mathrm{~mm}$ in diameter. The speed of the screw was kept constant at $38 \mathrm{rpm}$ for each of the assays, and the speed of the feeding system was adjusted to $28 \mathrm{rpm}$. The temperatures in zones 1 and 2 were kept constant at $60^{\circ} \mathrm{C}$ and $90^{\circ} \mathrm{C}$, respectively, and that in zone 3 varied according to the experimental design. The feed moisture also remained constant at $25 \%$ in all of the assays. The samples processed by extrusion were milled in a knife mill (Pulvex Model 200, Maquinaria para Moliendas y Mezclas, Mexico, D.F.) and sifted through a mesh of $60(250 \mu \mathrm{m})$ for subsequent analyses.

\subsection{Physicochemical analyses}

\section{Chemical analyses}

The fat and protein analyses were performed according to the official Association... (1999) methods: Protein (988.05) and fat (920.35). The moisture content was determined using the oven method with air circulation, and the ash content was determined by direct calcination of the sample. Cellulose, hemicellulose, and lignin were analyzed according to the procedures of Van Soest (1963), as Acid Detergent Fiber (ADF) (cellulose and lignin), and Van Soest and Wine (1967), as Neutral Detergent Fiber (NDF) (cellulose, hemicellulose and lignin). Hemicellulose was calculated as the difference between the registered values for NDF and ADF. Cellulose was estimated from the difference between the registered values for the residue of $\mathrm{ADF}$ and lignin. Lignin was separated from

Table 1. Codified and original values of independent variables.

\begin{tabular}{ccccc}
\hline & Codified variables & & \multicolumn{2}{c}{ Original variables } \\
\hline Assay & $\left(\mathrm{X}_{1}\right)$ & $\left(\mathrm{X}_{2}\right)$ & $\mathrm{FC}(\%)$ & $\mathrm{BT}\left({ }^{\circ} \mathrm{C}\right)$ \\
\hline 1 & -1.00 & -1.00 & 3 & 125 \\
3 & 1.00 & -1.00 & 15 & 125 \\
4 & -1.00 & 1.00 & 3 & 150 \\
5 & 1.00 & 1.00 & 15 & 150 \\
6 & -1.41 & 0.00 & 0.5 & 138 \\
7 & 1.41 & 0.00 & 17.5 & 138 \\
8 & 0.00 & -1.41 & 9 & 120 \\
9 & 0.00 & 1.41 & 9 & 155 \\
10 & 0.00 & 0.00 & 9 & 138 \\
11 & 0.00 & 0.00 & 9 & 138 \\
12 & 0.00 & 0.00 & 9 & 138 \\
13 & 0.00 & 0.00 & 9 & 138 \\
\hline $\mathrm{X}_{1}=$ FC: Fiber content; $\mathrm{X}_{2}=$ BT: Barrel temperature. & & 9 & 138 \\
\hline & & 0.00 & &
\end{tabular}


cellulose with sulfuric acid (72\%) from the ADF residue and was gravimetrically calculated.

\section{Physical analyses}

\section{Expansion index (EI)}

The EI was measured by dividing the average diameter of the extruded product by the internal diameter of the exit opening of the extruder (die) using a digital Vernier (Mitutoyo Corp., model CD-6 C5, DIGIMATIC, Japan). The EI was calculated as the mean of 15 random measurements for each extrudate.

\section{Luminosity}

Representative samples of each treatment were placed in a circular container ( $80 \mathrm{~mm}$ diameter and $20 \mathrm{~mm}$ depth), and it was then covered with a clear glass ( $2 \mathrm{~mm}$ thickness). Using a tristimulus colorimeter equipment (HunterLab miniscan XE, Mod 45/0-L, Hunter associates Laboratory, Inc. Reston VA, USA) 5 points on surface were obtained, and the $L$ value means were measured.

Water absorption index (WAI) and water solubility index (WSI)

WAI and WSI were determined according to the methodology described by Anderson et al. (1969).

Gel formation and gel strength

Extruded samples were heated using the heating cycle of the Rapid Visco Analyzer 3C (Newport Scientific Pty Ltd.,Sydney, Australia) at $92{ }^{\circ} \mathrm{C}$ for 5 minutes, cooled at room temperature, and refrigerated to $5{ }^{\circ} \mathrm{C}$ for 18 hours. The suspension was left at room temperature for 2 hours and the formation of gel was registered (LENCHIN et al., 1985). Gel strength was measured according to the method described by National Starch and Chemical Corporation (LENCHIN et al., 1985) using a universal TA-XT2 Texture Analyzer (Texture Technologies Corp., Scarsdale, NY, USA; Stable Micro System, Godalming, Surrey, UK) in the compression puncture mode to record the force required to penetrate the gel. The samples were placed transversally on the platform over a $1 \mathrm{~cm}$ thick metal sheet, and punctured with a $12.5 \mathrm{~mm}$ diameter cylindrical probe. The texturometer head moved the probe downward at a speed of $5 \mathrm{~mm} / \mathrm{s}$ to a $4 \mathrm{~mm}$ penetration distance. Four replicates were made per treatment. The measurements of gel adhesivity were performed with one compression cycle. Gel adhesivity was calculated as the negative force area obtained after the compression cycle representing the work necessary to pull the compressing plunger away from the sample.

\subsection{Experimental design and data analysis}

In accordance with the response surface methodology (STAT-EASE, 2003), the experimental data were used to determine the coefficients of the equation of expansion from
Taylor's series (quadratic polynomial); its general expression is (Equation 1):

$Y i=\beta_{0}+\beta_{1} X_{1}+\beta_{2} X_{2}+\beta_{11} X_{1}^{2}+\beta_{22} X_{2}^{2}+\beta_{12} X_{1} X_{2}+\varepsilon$

where $Y_{i}$ is the generic response function and $X_{1}, X_{2}$ independent variables. The $\beta$ s are the coefficients estimated by the methods of squared minimums and $\varepsilon$ the experimental error, represented by a normal distribution with a mean of zero and a variation equal to squared sigma. The significance of the model was justified through the analysis of variance (test $F$ ), and the influence of the variables was shown using graphs of response surface. The response surface methodology was used to obtain the optimum conditions of processing. The levels were codified as follows: Independent variables: $\mathrm{X}_{1}=\mathrm{FC}=$ Fiber content (\%) and $\mathrm{X} 2=\mathrm{BT}=$ Barrel Temperature $\left({ }^{\circ} \mathrm{C}\right)$. The values of the variation levels, the codification, and the design matrix used (Table 1 ) were analyzed according to a central composite design rotatable design $(\alpha=1.41)$ whit 5 centrals points that gives a total of 13 tests. The repetitions at the central point enabled to estimate the variability. The evaluated variables of response were: expansion index, luminosity, water absorption index, and water solubility index.

The preliminary data were analyzed using the response surface methodology and applying the statistical DesignExpert v.6.010. software (STAT-EASE, 2003). A second-order polynomial was employed to predict experimental behavior.

\section{Results and discussion}

Dietary fiber (DF) is the edible portion of plants (or analogous carbohydrates), which is resistant to digestion and adsorption in the human small intestine with complete or partial fermentation in the large intestine (RANHOTRA et al., 1991). The neutral detergent fiber (NDF) method (VAN SOEST, 1967) was developed to separate dry matter into a soluble fraction that is readily digested and a fibrous fraction that is slowly and incompletely digested. In plant materials, NDF consists primarily of hemicellulose, cellulose, and lignin, but it also contains small amounts of protein and ash. Acid detergent fiber $(\mathrm{ADF})$ is the insoluble residue following extraction of cell wall constituents with acid detergent minus hemicellulose.

The values found for raw bagasse fiber were: crude fiber $45.35 \%$, neutral detergent fiber (NDF) $90.38 \%$ and acid detergent fiber (ADF) $63.35 \%$, hemicellulose $27.03 \%$, cellulose $51.53 \%$, and lignin $11.82 \%$. The chemical constituents of bagasse are NDF, ADF, cellulose, hemicellulose, and lignin ranging from 53.8-90.5, 53.1-64.4, 55-58, 26-32 and 19$22 \mathrm{~g} .100 \mathrm{~g}^{-1}$, respectively (BARQUINERO, 1999; SANGNARK; NOOMHORM, 2004).

\subsection{Physicochemical characterization of the extruded blends}

The studied response variables of extruded blends were grouped into: chemical analyses (ether extract, protein, and fiber) and physical analyses (expansion index, luminosity, water absorption index and water solubility index, penetration force in gel, and adhesive force in gel). The prediction model 
was significant at different levels shown in Table 2. The results of the physical analyses are illustrated by means of response surface graphs.

\subsection{Chemical composition of extruded products}

Assays 1, 4, 6, and 13 were selected for subsequent analysis considering all fiber range formulated in the blends (Table 3 ). Assay $6\left(17.5 \% \mathrm{FC}, 138^{\circ} \mathrm{C}\right.$ barrel temperature), followed by assay 4 , showed the highest content of ADF, NDF, lignin, hemicellulose, and cellulose compared with the rest of the assays. FC was the variable that had the maximum effect on the fiber components of extruded blends. Assays 1 and 13, with the lowest FC, showed the lowest values of fiber components. The extrusion process led to the breakdown of the components, probably due to their fragmentation into sugars of lower molecular weight and the formation of resistant starch during the extrusion treatment (GAJULA et al., 2008).

According to Larrea et al. (2005a) this effect would be the result of the breakage of covalent and non-covalent linkages between carbohydrates and proteins associated with the fiber, which would produce small and more soluble molecular fragments. These authors also added that the extrusion process promoted redistribution of the insoluble dietary fiber as soluble dietary fiber, decreasing hemicellulose, proteins, and lipids and increasing lignin and ash and sugar contents in the alcoholic

Table 2. Regression coefficients and variance analysis of the mathematical models of the response variables.

\begin{tabular}{ccccccc}
\hline Coefficients & $\mathrm{EI}$ & $\mathrm{L}$ & $\mathrm{WAI}$ & $\mathrm{WSI}$ & $\mathrm{Pf}$ & $\mathrm{Af}$ \\
\cline { 2 - 7 } & $\mathrm{Y}_{\mathrm{IE}}$ & $\mathrm{Y}_{\mathrm{L}}$ & $\mathrm{Y}_{\mathrm{IAA}}$ & $\mathrm{Y}_{\mathrm{ISA}}$ & $\mathrm{Y}_{\mathrm{Fp}}$ & $\mathrm{Y}_{\mathrm{Fa}}$ \\
\hline Interactions & \multicolumn{7}{c}{} & & & \\
\hline$\beta$ & 1.75 & 60.71 & 5.68 & 6.34 & 59.51 & -5.45 \\
\hline Linear & & & & & \\
\hline$\beta_{1}$ & $0.017_{\mathrm{NS}}$ & $-6.05^{* * *}$ & $0.29^{*}$ & $-1.00^{* * *}$ & $-3.65_{\mathrm{NS}}$ & $0.38_{\mathrm{NS}}$ \\
$\beta_{2}$ & $-0.061^{* *}$ & $-1.10^{* *}$ & $0.74^{* * *}$ & $-0.35_{\mathrm{NS}}$ & $-19.87^{*}$ & $-0.46^{*}$ \\
\hline Quadratic & \multicolumn{7}{c}{} & & \\
\hline$\beta_{11}$ & $-0.065^{* *}$ & $2.28^{* * *}$ & $-0.045_{\mathrm{NS}}$ & $-0.77^{*}$ & $-21.00^{*}$ & $-0.47^{*}$ \\
$\beta_{22}$ & $-0.16^{* * *}$ & $-0.26_{\mathrm{NS}}$ & --- & --- & $47.33^{* * *}$ & $-0.18_{\mathrm{NS}}$ \\
\hline Interactions & \multicolumn{7}{c}{} & & \\
\hline$\beta_{12}$ & $-0.032_{\mathrm{NS}}$ & $0.64_{\mathrm{NS}}$ & $0.068_{\mathrm{NS}}$ & --- & --- & --- \\
$\mathrm{R}^{2}$ & 0.8587 & 0.9759 & 0.7061 & 0.6161 & 0.7173 & 0.4793 \\
$\mathrm{P} \leq$ & 0.0069 & $<0.0001$ & 0.0285 & 0.0288 & 0.0247 & 0.1 \\
\hline
\end{tabular}

EI: Expansion index; L: Luminosity; WAI: Water absorption index; WSI: Water solubility index; Pf: Penetration force in gel; Af: Adhesive force in gel. ${ }^{\star}$ Level of Significance at $\mathrm{p} \leq 0.10,{ }^{* *}$ Level of Significance at $\mathrm{p} \leq 0.05,{ }^{* * *}$ Level of Significance at $\mathrm{p} \leq 0.01, \mathrm{NS}=$ not significant.

Table 3. Some fiber components of selected extruded blends.

\begin{tabular}{lrrrr}
\hline $\begin{array}{c}\text { Component } \\
(\%)\end{array}$ & Assay 1 & Assay 4 & Assay 6 & Assay 13 \\
\hline ADF & $2.3 \pm 0.03^{\mathrm{d}}$ & $9.5 \pm 0.23^{\mathrm{a}, \mathrm{b}}$ & $12.0 \pm 0.57^{\mathrm{a}}$ & $6.2 \pm 0.02^{\mathrm{b}, \mathrm{c}}$ \\
$\mathrm{NDF}$ & $11.3 \pm 0.37^{\mathrm{d}}$ & $44.1 \pm 0.25^{\mathrm{a}}$ & $27.8 \pm 0.07^{\mathrm{b}}$ & $18.5 \pm 0.08^{\mathrm{c}}$ \\
Lignin & $0.34 \pm 0.05^{\mathrm{d}}$ & $1.5 \pm 0.57^{\mathrm{b}}$ & $2.6 \pm 0.06^{\mathrm{a}}$ & $1.0 \pm 0.06^{\mathrm{c}}$ \\
Hemicellulose & $9.0 \pm 0.57^{\mathrm{d}}$ & $14.6 \pm 0.32^{\mathrm{a}, \mathrm{b}}$ & $16.1 \pm 0.57^{\mathrm{a}}$ & $12.3 \pm 0.57^{\mathrm{c}}$ \\
Celullose & $1.9 \pm 0.57^{\mathrm{d}}$ & $8.0 \pm 0.57^{\mathrm{a}, \mathrm{b}}$ & $9.1 \pm 0.57^{\mathrm{a}}$ & $5.1 \pm 0.57^{\mathrm{c}}$ \\
\hline
\end{tabular}

ADF: Acid detergent fiber; NDF: Neutral detergent fiber; a: dry basis. extract. According to some researchers (RALET et al., 1991) it is also possible that some of the fiber components were solubilized into small units and were not completely recovered during the alcoholic precipitation thus causing variations during the determination. Arrigoni et al. (1986) reported that the thermal treatment of apple pulp promoted the solubilization and further degradation of the constituents of the alimentary fiber, especially arabans (RALET et al., 1993).

These assays (4 and 6), processed at the highest barrel temperature, had the highest FC. Nevertheless, in most assays the decrease in IDF was greater than the complementary increase in SDF. Probably, a fraction of the IDF was being fragmented into sugars lower molecular weight due to the extrusion treatment. Additionally, an increase in TDF due to extrusion was attributed to the formation of resistant starch (GAJULA et al., 2008). The results found in the present study are similar to those reported by Larrea et al. (2005a) for extruded orange pulp; these authors found higher values of SDF when the barrel temperature reached $140^{\circ} \mathrm{C}$.

According to Ralet et al. (1991), the increase in SDF was attributed to a partial solubilization of the IDF without a complete degradation of the polymeric structure. The present study results also agree with those previously reported by many different authors (CAMIRE; KING, 1991; BERGLUND et al., 1994; CAPREZ et al., 1986). Those researchers found that the values of soluble fiber generally increase after the extrusion process; although, the solubility of the dietary fiber may depend on the conditions of the extrusion process and on the method of analysis used (RALET et al., 1991). Larrea et al. (2005a) reported that during the extrusion process the IDF decreased whereas the SDF increased with an increasing content of total soluble pectin resulting from the solubilization of pectic substances. The extrusion precooking of wheat flours increased SDF by 22 to $73 \%$ and decreased IDF by 24 to $37 \%$, depending on the amount of bran added (GOURGUE et al., 1994). According to Dreher (1987), it is important to consider the proportions of SDF and IDF, as well as the quality of these components in regard to their effects; therefore it becomes necessary to combine these sources in order to obtain the maximum possible benefit.

\subsection{Effect of extrusion variables on the blends}

\section{Expansion index (EI)}

The values of EI varied from 1.39 to 1.79 , as indicated in Table 4. The analysis of regression showed that the EI was affected by the barrel temperature (BT) $(\mathrm{p} \leq 0.043)$ and by FCFC $(\mathrm{p} \leq 0.0436)$ and BT-BT $(\mathrm{p} \leq 0.0007)$ interactions.

The prediction model (Table 2) used explained $85.87 \%$ of the total variation $(\mathrm{p} \leq 0.0069)$ for the EI values (Table 4$)$. The maximum values of EI were found at $12 \% \mathrm{FC}$ and $138^{\circ} \mathrm{C} \mathrm{BT}$. As the barrel temperature decreased, the value of EI slightly decreased; nevertheless, when the FC and the BT increased ( $15 \%$ and $150^{\circ} \mathrm{C}$, respectively), the value of EI decreased more significantly (1.50). However, at intermediate values of FC, a contrary effect on the EI was found (Figure 1). Probably, the addition of WPC influenced the EI since a higher concentration 
of WPC (20.5\%) produced the highest values of EI, whereas the lowest values of this component (17.5\%) decreased the EI. In addition, high BT increased the amount of fragmented starch and the percentage of insoluble and denaturalized protein thus lowering the EI. Previous studies have shown that the maximum values of EI were found with blends of starch and casein or whey protein in concentrations of less than 10\% (FERNÁNDEZGUTIÉRREZ et al., 2004; AMAYA-LLANO et al., 2007). The EI of starchy products was found to be related to the severity of the extrusion process, and therefore to the plastification of the material. At low BT, the friction inside the extruder, and consequently the plasticized material, may not have been sufficient to produce a high degree of expansion. On the other hand, at high BT the internal pressure produced by increasing the FC could have degraded the material, which would have been reflected in a decreased EI.

During extrusion, the WPC (25\%) and fiber content (15\%) act as diluents of starch, thereby decreasing the EI. It is also probable that the denaturized protein lost solubility and became insoluble and aggregate thus decreasing the EI. Guy and Horne (1988) reported that the presence of fiber causes the fragmentation of cell membranes and prevents the gas bubbles from expanding to their maximum capacity. These authors consider that this is probably due to an increase in the viscous dissipation of the mass, which would increase the friction between the material fed in and the surface of the barrel.

In general, intermediate values of $\mathrm{BT}$ and $\mathrm{FC}$ tend to favor the EI. Aguilar-Palazuelos et al. (2007) reported that decreasing the feed moisture content resulted in higher expansion in blends of extruded potato starch and coconut fiber. At a lower BT with an increase in FC, the EI also increased; whereas a combination of high BT and an increase in FC content lowered the EI. As demonstrated previously (GUY; HORNE, 1988), when starch is extrusion-cooked, expansion is dependent on the formation of a starch matrix that entraps the water vapor resulting in the formation of bubbles. Above the critical concentration, the fiber molecules disrupt the continuous structure of the melt impeding

Table 4. Experimental design and response variables.

\begin{tabular}{ccccccc}
\hline \multirow{2}{*}{ Assays } & \multicolumn{2}{c}{ Original variables } & & \multicolumn{3}{c}{ Response variables } \\
\cline { 2 - 3 } \cline { 5 - 7 } & FC $(\mathrm{X} 1)$ & BT $(\mathrm{X} 2)$ & & EI & Pf & Af \\
\hline 1 & 3 & 125 & & 1.582 & 60.31 & -5.19 \\
2 & 15 & 125 & & 1.690 & 56.80 & -4.43 \\
3 & 3 & 150 & & 1.417 & 60.01 & -7.33 \\
4 & 15 & 150 & & 1.397 & 67.34 & -6.26 \\
5 & 0.5 & 138 & & 1.602 & 52.98 & -5.95 \\
6 & 17.5 & 138 & & 1.635 & 29.62 & -6.41 \\
7 & 9 & 120 & & 1.458 & 238.05 & -6.72 \\
8 & 9 & 155 & & 1.438 & 116.96 & -7.02 \\
9 & 9 & 138 & & 1.754 & 58.48 & -4.58 \\
10 & 9 & 138 & & 1.798 & 63.37 & -5.50 \\
11 & 9 & 138 & & 1.655 & 62.76 & -5.80 \\
12 & 9 & 138 & & 1.750 & 55.89 & -5.80 \\
13 & 9 & 138 & & 1.767 & 52.68 & $-5,20$ \\
\hline
\end{tabular}

FC: Fiber content (\%); BT: Barrel temperature $\left({ }^{\circ} \mathrm{C}\right)$; Values in parentheses refer to the codified levels. EI: Expansion index; Pf: Penetration force in gel; Af: Adhesive force in gel. its elastic deformation during expansion. Fibers are also able to bind some of the moisture present in the matrix thus reducing its availability for expansion.

\section{Luminosity (L)}

The L-values (luminosity) varied from 55.71 to 73.80 (data not shown). The maximum value of $\mathrm{L}$ was found at lower values of $\mathrm{FC}(0.5 \%)$ and a $\mathrm{BT}$ at $138^{\circ} \mathrm{C}$. As the fiber content was increased, the value of $\mathrm{L}$ decreased, and the lowest value (55.71) was found with $15 \% \mathrm{FC}$ and $\mathrm{BT}$ at $150{ }^{\circ} \mathrm{C}$ (Figure 2). This is attributable to the natural dark color of the fiber, whereas the white color of the corn starch and the WPC increased the $\mathrm{L}$ - values. The changes in the $\mathrm{L}$-values also resulted from the reaction of Maillard between reducing sugars (dextrinized starch) and amino groups of the protein. The effects of the FC on the L-values were influenced mainly by the residues of sugar and lignin present in the fiber, which produced a dark color. In addition, the different shades found with different fiber concentrations might be due to reactions originating during the extrusion process and causing the pigment degradation. The reactions that can affect the color during the extrusion process are diverse and basically include Maillard, caramelization, hydrolysis, and others, as well as non-enzymatic ones such as the degradation of pigments (CAMIRE; KING, 1991). Nevertheless, color can also be an indicator of the intensity of the process, and is related to chemical changes (AMAYA-LLANO et al., 2007). The regression analysis showed that the $L$ parameter was influenced by the FC ( $\mathrm{p} \leq 0.0001)$, BT ( $\mathrm{p} \leq 0.0253)$, and FC-FC interactions $(\mathrm{p} \leq 0.0009)$. The prediction model for

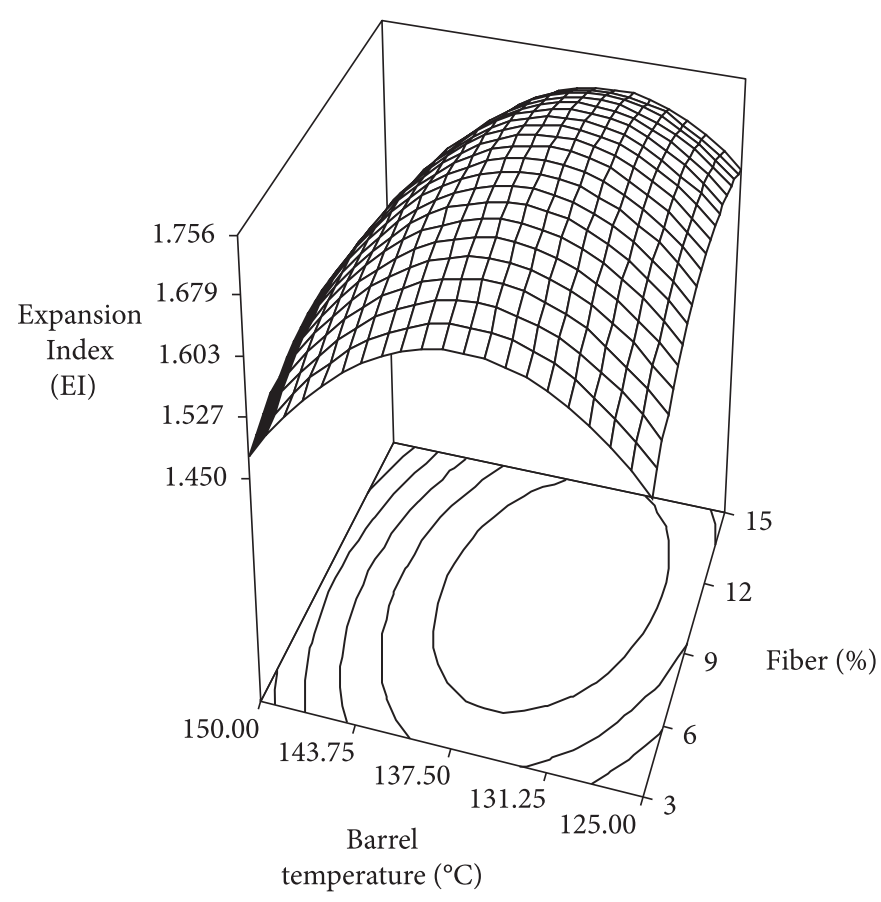

Figure 1. Effect of fiber and temperature interaction on the expansion index (EI). 
the L-response variable used the following codified variables (Equation 2):

$Y_{E I}=1.75+0.017 * X_{1}-0.061 * X_{2}-0.065 * X_{1} * X_{1}-$

$-0.16 * X_{2} * X_{2}-0.032 * X_{1} * X_{2}$

Utilizing original variables (Equation 3):

$Y_{E I}=17.09749-0.094611 * F C-0.27264 * B T-1.81738 E-$

$-003 * F C * F C-9.95259-004 * B T * B T-4.29151 E-004 * F C * B T$

The prediction model used explained $97.59 \%$ of the total variation ( $\mathrm{p} \leq 0.0001$ ) for the $\mathrm{L}$ values (Table 2 ).

\section{Water absorption index (WAI)}

The maximum value of WAI (6.8) was found at $150{ }^{\circ} \mathrm{C}$ BT and $15 \% \mathrm{FC}$. These conditions are probably sufficient to open the porous structure of the core fiber allowing more water to enter into contact with the hydrophilic groups. The WAI decreased as the $\mathrm{BT}$ decreased, the lowest value was reached at the lowest BT of the process $\left(120^{\circ} \mathrm{C}\right)$ with an FC value of $9 \%$ (Figure 3). These changes in the WAI were due to the effect of the variables used in this study: an increase in the plasticization of starch granules opened their structure, which results in high water absorption and promotes the increasing in water absorption. Nevertheless, increasing the severity of the process causes a breaking of the swollen and hydrated granules, which results in low WAI values (SAGAR; MERRIL, 1995). Moraru and Kokini (2003) reported that an increase in BT as well as a decrease in FM could cause an increase in the plasticization of the extruded materials. On the other hand, when the FC is increased in an extruded product, the effort of cutting in the interior of the extruder favors the plasticization and homogenization of the processed materials (GUAN et al., 2004). The results found in this study agree with those reported by Larrea et al. (2005a). Those authors reported that high WAI values in extruded orange pulp fiber were found under severe conditions, especially at temperatures close to $150^{\circ} \mathrm{C}$. In the present study, the values of the WAI in the extruded blends varied from 4.25 to 6.87 units (data not shown). The regression analysis showed that the WAI was influenced by the FC $(\mathrm{p} \leq 0.1)$ and by the BT $(\mathrm{p} \leq 0.0036)$.

The prediction model used explained $70.61 \%$ of the total variation $(\mathrm{p} \leq 0.0285)$ in the values of the WAI (Table 2$)$.

\section{Water solubility index (WSI)}

The maximum value for the WSI was 7.72 at $150{ }^{\circ} \mathrm{C}$ BT and $3 \%$ FC. The WSI decreased as the FC increased, and the lowest value (4.184) occurred with the highest FC: $17.5 \%$ (Figure 4). The regression analysis showed that the WSI was influenced by the FC ( $\mathrm{p} \leq 0.0158)$ and FC-FC interactions ( $\mathrm{p} \leq 0.0609)$. It was also observed that by raising the barrel temperature, the amount of fragmented starch increased. This increased the WSI due to the shear effect and low moisture content, whereas a higher FC resulted in higher solubility of the blend attributable to a lower degradation of its components or to a probable interaction among them. Ralet et al. $(1991,1993)$ reported that extrusion increased the water solubility of beet pulp from 16.6 to as much as $47.5 \%$ and that of pea hull fiber from 3.6 up to15.3\%.

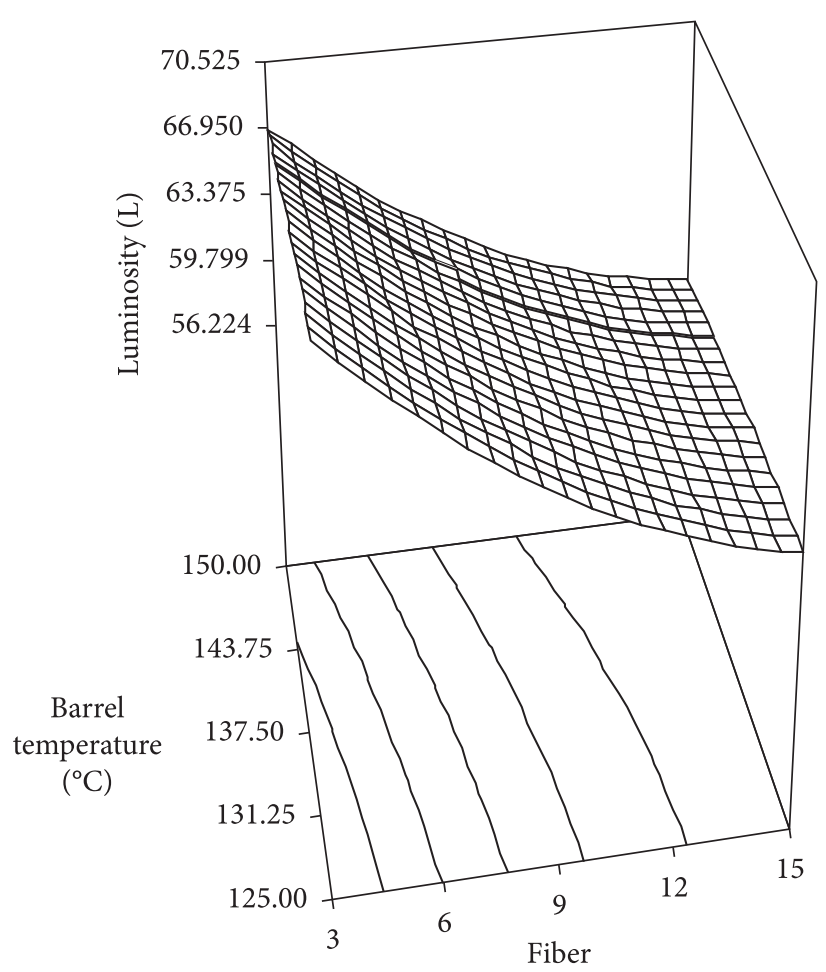

$(\%)$

Figure 2. Effect of fiber and temperature interaction on luminosity (L).

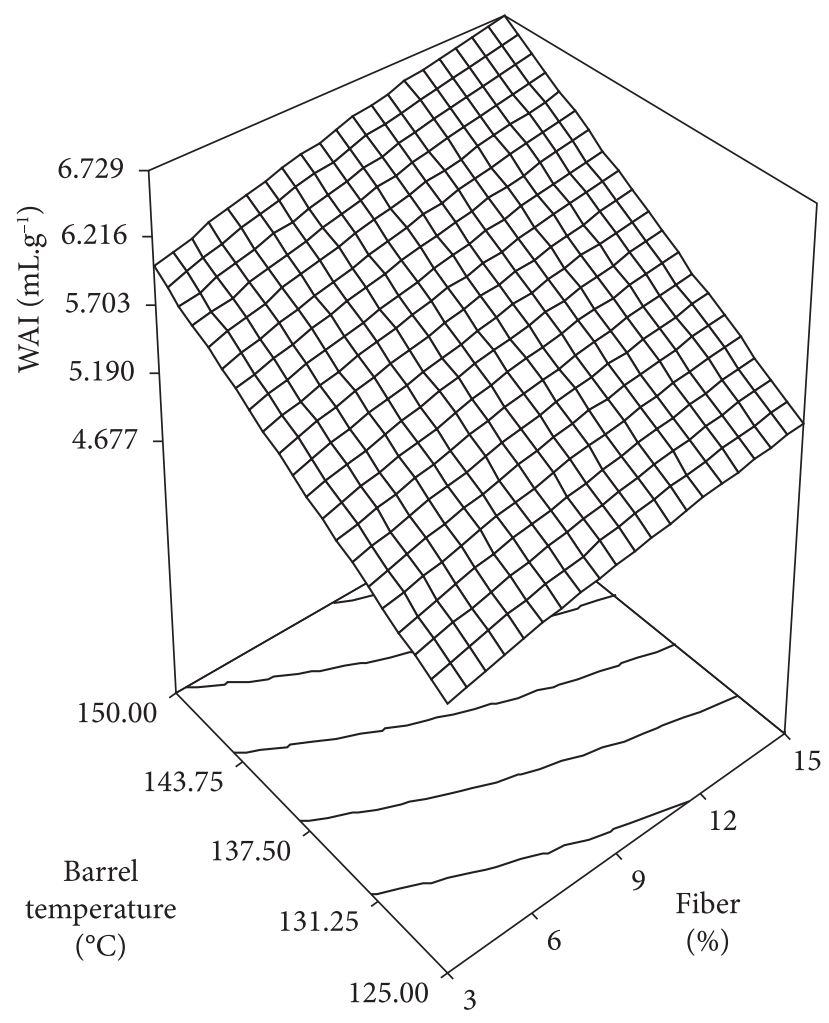

Figure 3. Effect of fiber and temperature interaction on the water absorption index (WAI). 


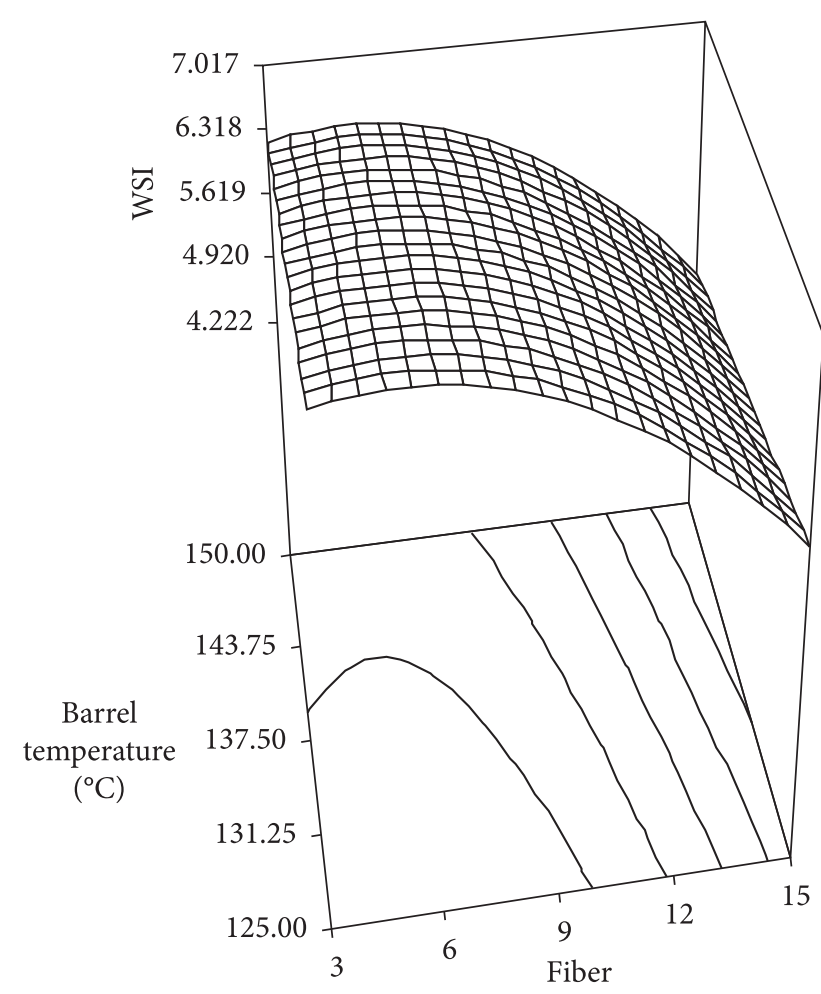

(\%)

Figure 4. Effect of fiber and temperature interaction on the water solubility index (WSI).

In addition, they indicated that the solubilized materials were pectic and hemicellulosic substances.

The prediction model used explained $61.61 \%$ of the total variation ( $\mathrm{p} \leq 0.0288$ ) in the WSI values (Table 2 ). The relatively high hydration capacity of the blends probably depends mainly on the inter-intra-molecular bonds among fiber, WPC, and amylose and amylopectin induced by extrusion conditions, as well as on the changes that these components undergo during extrusion. Hashimoto and Grossmann (2003) reported that an increase in bran content tended to decrease the WSI in extruded cassava bran/cassava starch blends; these authors explain that structural modifications involving bran fiber could be responsible for increasing the WAI and decreasing the WSI, and that this modification could have resulted in interactions between fiber and starch reducing the solubility.

\section{Gel Penetration force (Pf)}

Starch and water dispersions heated above their gelatinization temperature behaved like viscoelastic pastes. Upon cooling, the paste thickens and may form an elastic gel if the dispersion has sufficient concentration (RING, 2006). The firmness of the gel depends on the extent of junction zone formation (BEMILLER; WHISTLER, 1996). Starch gels are commonly regarded as composite systems consisting of swollen particles embedded in a three-dimensional network of aggregated amylose chains. During the cooling, the effect of hydrogen bonds in the gel matrix gradually increased, especially at low temperature (TSAI et al.,
1997). Gelation is the phenomenon in which associations between the polymer chains become visible to form a continuous threedimensional network, and its firmness is an interesting aspect that must be evaluated to determine its use in industrial food formulation and other applications (AGUILERA; ROJAS, 1996). The Pf is the maximum force that is applied in a descending direction to indicate cohesion (force applied by tongue towards the palate to deform food). It is an indirect analysis of viscosity and is associated with starch retrogradation, which indicates a better combination of the starch components and means that, during the food processing, the conditions were not severe thus permitting their functional characteristics to positively influence the elaborate a product. For instance, stabilizers such as gelatin, carrageenan, alginate, pectin, and starch or starch derivatives are added to formulations of milk-based custards and yogurts to improve viscosity and texture, minimize syneresis, and increase stability throughout storage life (THOMAS; ATWELL, 1999). Since pastes and gels produced from native starches are often cohesive (gummy) or rubbery, the modification of the molecular weight and the starch amylose/amylopectin ratio may improve the functional properties of dairy products (THOMAS; ATWELL, 1999). The values of Pf varied from 29.62 to $238.05 \mathrm{kgf}$ (Table 4). The maximum Pf values were found for the samples formulated with intermediate $\mathrm{FC}(9 \%)$ and low or high BT $\left(120\right.$ or $\left.155^{\circ} \mathrm{C}\right)$. It is likely that the fiber increased the compact structure of the extruded blends as revealed by higher $\mathrm{BD}$ and lower EI values. Aguilera and Rojas (1996) reported that the use of $20 \%$ of cassava starch in blends with isolate protein concentrate improved the viscoelastic properties of the blend. Those authors observed a mixed gel made up of a continuous network of protein gel around swollen granules of cassava, and added that the thermal induction of gels could originate a special type of gel of separated phase. The regression analysis showed that the $\mathrm{Pf}$ was affected by the BT $(\mathrm{p} \leq 0.1)$, FC-FC $(\mathrm{p} \leq 0.1)$, and BT-BT $(\mathrm{p} \leq 0.0071)$.

The used prediction model explained $71.73 \%$ of the total variation $(p \leq 0.0247)$ for the Pf values (Table 2$)$.

\section{Adhesive force in gel (Af)}

The force applied to the gel in an ascending direction indicates its adhesiveness. Similar to Pf, the Af is an indirect indicator of viscosity, as well as of the conditions of the process since a smaller adhesive force is associated with a smaller reconstruction of the starch components. Therefore, severe damage of the components would be reflected in the rheological properties of the product (viscosity). The values of Af varied from $-7,329$ to $-4,428 \mathrm{kgf}$ (Table 4). The highest value of Af was found for the sample with the minimum FC (3\%) and the highest BT $\left(155^{\circ} \mathrm{C}\right)$, whereas the lowest was found for the sample formulated with maximum FC (15\%) and the lowest BT $\left(125^{\circ} \mathrm{C}\right)$. The regression analysis showed that the Af was affected by the BT $(\mathrm{p} \leq 0.1)$ and FC-FC $(\mathrm{p} \leq 0.1)$. The prediction model used explained $47.93 \%$ of the total variation (Table 2 ).

\section{Conclusions}

Barrel temperature was the variable of maximum effect on the total fiber composition. Intermediate values of barrel temperature and fiber contents in the blends proved to be the 
most favorable conditions for the expansion index, whereas high fiber contents and high barrel temperatures decreased the expansion values. An increase in the fiber content caused decreases in the luminosity values. Severe extrusion conditions increased the values of the water absorption index and water solubility index, and they increased penetration and decreased the adhesive force in gels. The extrusion process improved the functional properties of sugarcane fiber bagasse enabling its addition to diverse alimentary systems.

\section{References}

AGUilar-PALAZUELOS, A. et al. Mechanical and structural properties of expanded extrudates produced from blends of native starches and natural fibers of henequen and coconut. Starch/Stärke, v. 59, p. 533-542, 2007.

AGUILERA, J. M.; ROJAS, E. Rheological, thermal and microstructural properties of whey protein-cassava starch gels. Journal of Food Science, v. 61, p. 962-966, 1996.

AMAYA-LLANO, S. L. et al. Functional Characteristics of Extruded Blends of Whey Protein Concentrate and Corn Starch. Cereal Chemistry, v. 84, p. 195-201, 2007.

ANDERSON, R. A. et al. Gelatinization of corn grits by roll and extrusion-cooking. Cereal Science Today, v. 14, p. 4-12, 1969.

ARRIGONI, E. et al. Chemical composition and physical properties of modified alimentary fibre sources. Food Hydrocolloids, v. 1, n. 57-67, 1986.

ASSOCIATION OF OFFICIAL ANALYTICAL CHEMISTS - AOAC. Official Methods of Analyses. 15. ed. AOAC, 1999. p. 807-811.

BARQUINERO, E. Composición físico-química y morfológica del bagazo. La Habana: Ed. Científico-Técnica, 1999. cap 1.

BEMILLER, J. N.; WHISTLER, R. L. Carbohydrates. In: FENNEMA, O. R. (Ed.). Food Chemistry. New York: Marcel Dekker, 1996. p. 157-223.

BERGLUND, P. T.; FASTNAUGHT, C. E.; HOLM, E. T. Physicochemical and sensory evaluation of extruded high-fiber barley cereals. Cereal Chemistry, v. 77, p. 91-95, 1994.

CAMIRE, M. E.; KING, C. C. Protein and fiber supplementation effects on extruded cornmeal snack quality. Journal of Food Science, v. 56, p. 760-763, 1991.

CAPREZ, A. et al. Influence of different types of thermal treatment on the chemical composition and physical properties of wheat bran. Journal of Cereal Science, v. 4, p. 233-239, 1986.

DREHER, M. L. Handbook of dietary fiber: an applied approach. New York: MarcelDekker, 1987. 468 p.

FERNANDEZ, M. et al. Dietary fibre from cane bagasse: A new alternative for use of these residues. Alimentaria, v. 277, p. 3738, 1996.

FERNÁNDEZ-GUTIÉRREZ, J. A. et al. Physicochemical properties of casein-starch interaction obtained by extrusion process. Starch/ Starke, v. 56, p. 190-198, 2004.

GAJUlA, H. et al. Precooked Bran-Enriched Wheat Flour Using Extrusion: Dietary Fiber Profile and Sensory Characteristics. Journal of Food Science, v. 4, p. 173-179, 2008.

GIUNTINI, E. B.; LAJOLO, F. M.; DE MENEZES, E. W. Dietary fiber potential in Iberian-American countries: Food, products and residues. Archives Latinoamericanos Nutrición, v. 53, p. 14$20,2003$.
GOULD, M. J. et al. High-fiber, noncaloric flour substitute for baked foods. Properties of alkaline peroxide treated lignocellulose. Cereal Chemistry, v. 66, p. 201-205, 1989.

GOURGUE, C. M. et al. Effect of extrusion- cooking on the hipoglycaemic properties of citrus fibre: An in vitro study. Journal Science and Food Agriculture, v. 64, p. 493-499, 1994.

GUAN, J. J.; FANG, Q.; HANNA, M. A. Selected functional properties of extruded starch acetate and natural fibers foams. Cereal Chemistry, v. 81, p. 199-206, 2004.

GUY, A.; HORNE, W. Extrusion and co-extrusion of cereals. In: BLANSHARD, J. M. V.; MITCHELL, J. V. (Eds.). Food Structure - Its Creation and Evaluation. London: Butterworths, 1988. p. 331-349.

HASHIMOTO, J. M.; GROSSMANN, M. V. E. Effects of extrusion conditions on quality of cassava bran/cassava starch extrudates. International Journal of Food Science and Technology, v. 38, p. 511-517, 2003.

HUFFMAN, L. M. Processing whey protein for use as a food ingredient. Food Technology, v. 50, n. 2, p. 49-52, 1996.

KESTERSON, J. W.; BRADDOCK, R. J. Processing and potential uses for dried juice sacs. Food Technology, v. 27, p. 50-54, 1973.

KURAKAKE, M.; OSAKA, H.; HARANO, Y. Pretreatment bagasse by UCT-solvent for enzymatic hydrolysis. Applied Biochemistry and Biotechnology, v. 27, p. 111-122, 1991.

LARREA, M. A.; CHANG, Y. K.; MARTÍNEZ-BUSTOS, F. Effect of some operational extrusion parameters on the constituents of orange pulp. Food Chemistry, v. 89, p. 301-308, 2005a.

LARREA, M. A.; CHANG, Y. K.; MARTINEZ-BUSTOS, F. Some functional properties of extruded orange pulp and its effect on the quality of cookies. Lebensmittel-Wissenschaft und-Technologie, v. 38, p. 213-220, 2005b.

LENCHIN, J. M.; TRUBiAnO, P. C.; HOFFMAN, S. Converted starches for use as a fat-or oil-replacement in foodstuffs. National Starch and Chemical Corporation. US 4510166, jan. 1984, 09 abr. 1985.

MORARU, C. I.; KOKINI, J. L. Nucleation and expansion During Extrusion and Microwave Heating of Cereal Foods. Comprehensive Reviews in Food Science and Food Safety, v. 2, p. 120-138, 2003.

PANDEY, A. et al. Biotechnological potential of agro-industrial residues. II: cassava bagasse. Bioresource Technology, v. 74, p. 8187, 2000.

RALET, M. C.; THIBAULT, J. F.; VALLE, D. G. Solubilization of sugar-beet pulp cell wall polysaccharides by extrusion-cooking. Lebensmittel-Wissenschaft und-Technologie, v. 24, p. $107-$ 112, 1991.

RALET, M. C. O.; VALLE, D. G.; THIBAULT, J. F. Raw and extruded fibre from pea hull. Part I: Composition and physics chemical properties. Carbohydrate Polymers, v. 20, p. 17-23, 1993.

RANHOTRA, J. A.; GELROTH, J. A.; EISENBRAUN, G. J. High-fiber white flour and its use in cookie products. Cereal Chemistry, v. 68, n. 4, p. 432-434, 1991.

RING, S. G. Some studies on starch gelation. Starch/Stärke, v. 37, p. 80-83, 2006.

ROSAMOND, W. D. Dietary fiber and prevention of cardiovascular disease. Journal of the American College of Cardiology, v. 39, p. 57-59, 2002.

SAGAR, A. D.; MERRIL, E. W. Starch fragmentation during extrusion processing. Polymer, v. 36, p. 1883-1886, 1995. 
SANGNARK, A.; NOOMHORM, A. Effect of dietary fiber from sugarcane bagasse and sucrose ester on dough and bread properties. Lebensmittel-Wissenschaft und-Technologie, v. 37, p. 697704, 2004.

SCHAEFER, A.; STINTZING, F. C.; CARLE, R. By-products of plant food processing as a source of functional compounds-recent developments. Trends Food Science and Technology, v. 12, p. 401-413, 2001.

SODINI, I. et al. properties of yogurt fortified with various commercial whey protein concentrates. Journal of the Science of Food and Agriculture, v. 85, p. 853-859, 2005.

STAT-EASE. Design-Expert version 6.0.5 Software. Minneapolis: Stat-Ease, Inc., 2003.

THOMAS, J.; ATWELL, A. Starches. Saint Paul: American Association of Cereal Chemists, 1999. p. 1-29.
TSAI, M. L.; LI, C. F.; LII, C. Y. Effects of granular structures on the pasting behaviors of starches. Cereal Chemistry, v. 74, p. 750757, 1997.

VAN SOEST, P. J. Use of detergents in the analysis of fibrous feed. II. A rapid method for the determination of fiber and lignin. Journal of the Association Official Analytical Chemists, v. 46, p. 829835, 1963.

VAN SOEST, P. J.; WINE, R. H. Use of detergents in the analysis of fibrous feeds. IV. Determination of plant cell-wall constituents. Journal of the Association Official Analytical Chemists, v. 50, p. 50-55, 1967.

VERDALET-GUZMÁN, I. et al. Caracterización de mezclas de fibra de caña de azúcar, almidón de maíz y concentrado de proteína de suero de leche, elaboradas mediante la tecnología de extrusión en el desarrollo de yogurt y galletas. In: SIMPÓSIO LATINOAMERICANO DE CIÊNCIAS EN ALIMENTOS SLACA, 7., 2007, Campinas, Brasil. Anais... Campinas, 2007. 